\title{
SCREENING OF DIFFERENT OKRA GENOTYPES AGAINST HEAT STRESS
}

\author{
Okra to heat stress \\ [Sumeera Asghar ]
}

\begin{abstract}
Okra (Abelmoscus esculentum L.) is an important summer vegetable of family Malvaceae. As temperature of the world is rising day by day due to climate change, the physiological behavior of crops is also changing and tolerance against heat is getting minimize. For this purpose, a research trial was conducted to screen different okra genotypes against high temperature $\left(45 / 35^{\circ} \mathrm{C}\right.$ day/night).Plants were grown in growth room at $\left(28 / 22{ }^{\circ} \mathrm{C}\right.$ day/night) temperature for four weeks. After four week temperature was gradually increased by $2^{\circ} \mathrm{C}$ to avoid sudden osmotic shock until the desired high temperature $\left(45 / 35^{\circ} \mathrm{C}\right.$ day/night) was achieved and genotypes were kept at this temperature for one week. Finding of this research showed wilting of seedlings, reduced leaves size, induced senescence and change of colour from green to yellow black, drastic decrease in fresh and dry matter contents reason can be the high transpiration rate disturbance or injuries in the physiological processes occurring within cell showed that $\mathrm{OH}$ 152, OH-713 and OH-139 were most tolerant genotypes in contrast Garnier and Green gold were found to be sensitive and Tokita was the most sensitive genotype among all genotypes. Their search findings conclude that heat stress had a significant effect on the physiological, morphological and biochemical mechanisms of Okra genotypes.
\end{abstract}

Keywords - heat stress, okra, tolerance, genotypes

\section{Introduction}

Okra (Abelmoscus esculentum L.)is an important annual summer vegetable of family Malvaceae (Siemonsma and Kouame, 2004) and is mainly propagated by seeds and has duration of 90-100 days. Okra is a nutritious vegetable being grown for its fibrous pods and seeds. Okra is said to be very useful against genito-urinary disorders, spermatorrhoea and prolonged dysentery (Nadkarni, 1927) Pakistani environmental conditions are suitable for its production but comparative pods production of okra in Pakistan is far less than the production statistics worldwide. Okra is very sensitive crop to the temperature. Poor fruit setting has been observed below $18^{\circ} \mathrm{C}$ and above $34^{\circ} \mathrm{C}$. High temperature

\section{sumeera Asghar}

University of agriculture Faisalabad

Pakistan

even for short duration can cause inhibition of photosynthesis, reduction in respiration, interrupts plant water status due to high rate of leaf transpiration and abortion of buds quality and viability of seed ( Abdul-Baki. 1991).Global warming affects economic development in many ways; agricultural economies have always depended on the Mercy of nature and climate. Climate change is a global phenomenon and no country is immune to it. Heat stress due to high temperature is a plain threat to crop production worldwide. (Hall, 2001). Gaseous discharge due to human activities are significantly adding to the existing concentration of greenhouse gases, particularly carbon dioxides $\left(\mathrm{CO}_{2}\right)$ methane $\left(\mathrm{CH}_{4}\right)$, chlorofluorocarbons (CFC) and nitrous oxide $\left(\mathrm{N}_{2} \mathrm{O}\right)$. Different global circulation models predict greenhouse gases will gradually increase the world's average ambient temperature. According to a report by the inter-governmental panel on climate change (IPCC), global mean temperature will raise $0.3^{\circ} \mathrm{Cper}$ decade (Jones et al.1999). At moderately high temperature, crop injuries and mortalities may occur in case of long-term exposure. Indirect injuries due to high temperature include inactivation of enzymes, inhibition of protein synthesis while in, direct injuries due to high temperature increased fluidity of membrane lipids, and cause protein denaturation, (Howarth, 2005).Plants modifies their metabolism in various means in response to high temperature (HT), primarily by producing compatible solutes that are capable to organize proteins and cellular structures, retain cell turgor by osmotic adjustment, and adjust the antioxidant system to re-establish the cellular re dox balance and homeostasis (Janska et al, 2010; Valliyodan et al 2006). In Pakistan like other crops, okra faces a dual threat of biotic and abiotic stresses including heat stress is one of them. As temperature is increasing day by day due to global warming around the world. The central Punjab has a semi-arid climate with hot summer having average temperature above $40^{\circ} \mathrm{C}$ According to a report by FAO maximum temperature peaks $45^{\circ} \mathrm{C}$ in May-July (FAO, 1998). In Punjab temperature had increased over the period 1960-2007 (2009). Generally in Pakistan now winter season is short (set late and ends early) while summer is long.as the climate changes so cropping patterns and crops. This research study was under taken to screen the different genotypes against heat stress.

\section{Materials and Methods}

The experiment was conducted in the growth room of the Institute of Horticultural Sciences at University of Agriculture Faisalabad. Temperature was controlled for first four weeks and after that one week heat stress was applied in which comparative response of the selected 16 okra genotypes (OH-152, OH-139, OH-713, OH-597, OH-2324, Okra-1548, Okra-7080, Kiran, Sitara-9101, Okra-7100, Click-5769, JKOH-456, Rama Krishna, Garnier, Tokita, Green Gold) were observed against heat stress. Germplasm collected from Ayub Agriculture Research Institute, Faisalabad. Seeds were first socked in Petri dishes for about 12 hours to soft seeds. Seed were sown in pots containing sand as growth media in March. There were four replication and five plants in each replication. Hoagland solution was 
Proc. of the Fourth Intl. Conf. Advances in Bio-Informatics, Bio-Technology and Environmental Engineering- ABBE 2016 Copyright (C) Institute of Research Engineers and Doctors, USA .All rights reserved.

ISBN: 978-1-63248-091-0 doi: 10.15224/ 978-1-63248-091-0-38

used as nutrient medium. Plants were kept in growth room under controlled temperature conditions such as optimum temperature $\left(28 / 22{ }^{\circ} \mathrm{C}\right.$ day/night). Heat stress was given four week after seedlings emergence. The temperature was raised by $2^{\circ} \mathrm{C}$ each day to avoid any shock until the desired high temperature level $\left(40 / 30^{\circ} \mathrm{C}\right.$ day/night) was attained. Plants were harvested and analyzed the effects of heat stress five days after achieving treatment temperature. After 28 days of growth, the seedlings were up rooted. Shoot length of five randomly selected seedlings from each lot was measured. Similarly root length of five randomly selected seedlings from each replicate was measured. The average of each replication was taken after the calculation of fresh weight of the seedlings that were enveloped in filter paper. For dry weights, the five randomly selected plants from each replicate were taken in paper bags and then placed in oven (Memmert-110, Schawabach) and dried at $70{ }^{\circ} \mathrm{C}$ for a week. The dry weights of both root and shoot were measured using digital balance. Following morphological, physiological and biochemical parameters were recorded. Shoot length $(\mathrm{cm})$, Root length $(\mathrm{cm})$, Number of leaves (counting) Shoot fresh weight $(\mathrm{g})$, Root fresh weight $(\mathrm{g})$, Shoot dry weight $(\mathrm{g})$, Root dry weight (g) Physiological and biochemical parameters Water use efficiency Chlorophylls contents (SPAD value) Stomatal conductance $\left(\mathrm{mmol} \mathrm{s}^{-1}\right)$ Leaf surface temperature $\left({ }^{\circ} \mathrm{C}\right)$ Photosynthetic rate (IRGALCi-SD ABC Bioscientitific, UK).Complete Randomized Design (CRD) with single factor was applied to the experiment, collected data was analyzed statistically by employing Fisher's analysis of variance technique (ANOVA) and significance of treatments was tested (Steel et al., 1997).

\section{Results}

\section{A. Morphological parameters}

Out of all selected genotypes, shoot length was observed to be maximum in $\mathrm{JKOH}-456(12.23 \mathrm{~cm})$ followed by the click-5769 and $\mathrm{OH}-152(11.75 \mathrm{~cm})$ which were at par, while minimum length was in okra-1548 $(7.75 \mathrm{~cm})$. Root length were found to be maximum in Rama Krishna $(11.20 \mathrm{~cm})$ followed by kiran $(10.08 \mathrm{~cm})$ and lowest length was of Click-5769 (5.58 cm) Shoot fresh weight was found to be maximum in $\mathrm{OH}-152(1.93 \mathrm{~g}) \mathrm{KJOH}-456(1.93 \mathrm{~g})$ followed by the OH-139 (1.74 g), kiran and Green Gold, while minimum shoot fresh weight was found in Okra-7100 (1.16 g) followed by Garnier (1.32 g). On the other hand, it was at par for other genotypes. Root fresh weight was recorded to be highest in okra-1548 (0.72 g), followed byclick-5769 $(0.62 \mathrm{~g})$ while lowest was recorded in OH-713 (0.27g) Shoot dry weight Out of all selected genotypes maximum values were recorded in $\mathrm{OH}-152(0.34 \mathrm{~g})$ followed by $\mathrm{OH}-139$ $(0.31 \mathrm{~g})$ and lowest amount was calculated in OH-597 $(0.18 \mathrm{~g})$. Root dry weight was found to be maximum Tokita $(0.280 \mathrm{~g})$ followed by Okra-1548 (1.63g) while minimum root dry weight was recorded in Sitra-9101 (105g). Maximum number of leaves was observed in Tokita (4.00) followed by the $\mathrm{OH}-152$ and $\mathrm{OH}-1391$ (3.75) which are at park while minimum number of leaves was observed okra1548 (2.50). All results were in accordance with the previous finding (Guilianiet al.1997). Excessive of radiation and high temperature are often the most limiting factors affecting plant growth and final crop yield high temperature can cause considerable pre damages, including burning of leaves, sunburns on leaves, branches and stems, leaf senescence, shoot and root growth inhibition, fruit discoloration and damage, and reduced yield.

Table 1. Overall comparison of mean values $(n=3)$ of shoot length, shoot fresh weight and shoot fresh weight of okra genotypes

\begin{tabular}{llll}
\hline Genotype & $\begin{array}{l}\text { Shoot Length } \\
\text { (cm) }\end{array}$ & $\begin{array}{l}\text { Shoot Fresh } \\
\text { Weight }(\mathbf{g})\end{array}$ & $\begin{array}{l}\text { Shoot Dry } \\
\text { Weight }(\mathbf{g})\end{array}$ \\
\hline OH-152 & $11.75 \pm 0.60 \mathrm{a}$ & $1.93 \pm 0.03 \mathrm{a}$ & $0.34 \pm 0.013 \mathrm{a}$ \\
OH-139 & $11.33 \pm 0.24 \mathrm{ab}$ & $1.74 \pm 0.08 \mathrm{ab}$ & $0.31 \pm 0.004 \mathrm{ab}$ \\
OH-713 & $10.50 \pm 0.74 \mathrm{a}-\mathrm{c}$ & $1.41 \pm 0.12 \mathrm{bc}$ & $0.20 \pm 0.027 \mathrm{bc}$ \\
OH-597 & $7.93 \pm 0.37 \mathrm{de}$ & $1.18 \pm 0.11 \mathrm{c}$ & $0.18 \pm 0.026 \mathrm{c}$ \\
OH-2324 & $10.40 \pm 0.40 \mathrm{a}-\mathrm{c}$ & $1.49 \pm 0.10 \mathrm{a}-\mathrm{c}$ & $0.22 \pm 0.021 \mathrm{a}-\mathrm{c}$ \\
Okra-1548 & $7.75 \pm 0.10 \mathrm{e}$ & $1.43 \pm 0.04 \mathrm{bc}$ & $0.21 \pm 0.019 \mathrm{bc}$ \\
Okra-7080 & $9.30 \pm 0.47 \mathrm{~b}-\mathrm{e}$ & $1.52 \pm 0.06 \mathrm{ac}$ & $0.24 \pm 0.011 \mathrm{a}-\mathrm{c}$ \\
Kiran & $11.63 \pm 0.28 \mathrm{ab}$ & $1.71 \pm 0.14 \mathrm{ab}$ & $0.27 \pm 0.026 \mathrm{a}-\mathrm{c}$ \\
Sitara-9101 & $10.00 \pm 0.65 \mathrm{a}-\mathrm{e}$ & $1.36 \pm 0.11 \mathrm{bc}$ & $0.20 \pm 0.030 \mathrm{c}$ \\
Okra-7100 & $10.60 \pm 0.64 \mathrm{ac}$ & $1.16 \pm 0.03 \mathrm{c}$ & $0.20 \pm 0.020 \mathrm{bc}$ \\
Click-5769 & $11.70 \pm 0.72 \mathrm{a}$ & $1.52 \pm 0.07 \mathrm{a}-\mathrm{c}$ & $0.23 \pm 0.021 \mathrm{a}-\mathrm{c}$ \\
JKOH-456 & $12.23 \pm 0.38 \mathrm{a}$ & $1.93 \pm 0.10 \mathrm{a}$ & $0.27 \pm 0.036 \mathrm{a}-\mathrm{c}$ \\
Rama Krishna & $10.30 \pm 0.25 \mathrm{a}-\mathrm{d}$ & $1.54 \pm 0.10 \mathrm{a}-\mathrm{c}$ & $0.24 \pm 0.022 \mathrm{a}-\mathrm{c}$ \\
Garnier & $8.28 \pm 0.27 \mathrm{c}-\mathrm{e}$ & $1.32 \pm 0.06 \mathrm{bc}$ & $0.21 \pm 0.013 \mathrm{bc}$ \\
Tokita & $8.28 \pm 0.27 \mathrm{c}-\mathrm{e}$ & $1.43 \pm 0.09 \mathrm{bc}$ & $0.25 \pm 0.021 \mathrm{a}-\mathrm{c}$ \\
Green Gold & $10.65 \pm 0.44 \mathrm{a}-\mathrm{c}$ & $1.67 \pm 0.09 \mathrm{ab}$ & $0.25 \pm 0.026 \mathrm{a}-\mathrm{c}$ \\
\hline
\end{tabular}

Table 2. Overall comparison of mean values $(n=3)$ of root length, root fresh weight and root fresh weight of okra genotypes

\begin{tabular}{llll}
\hline Genotype & $\begin{array}{l}\text { Root Length } \\
\text { (cm) }\end{array}$ & $\begin{array}{l}\text { Root Fresh } \\
\text { Weight }(\mathbf{g})\end{array}$ & $\begin{array}{l}\text { Root Dry } \\
\text { Weight }(\mathbf{g})\end{array}$ \\
\hline OH-152 & $6.50 \pm 0.46$ ef & $0.47 \pm 0.056 \mathrm{be}$ & $0.125 \pm 0.028 \mathrm{~b}$ \\
OH-139 & $6.50 \pm 0.46$ ef & $0.34 \pm 0.020 \mathrm{de}$ & $0.098 \pm 0.009 \mathrm{~b}$ \\
OH-713 & $7.08 \pm 0.22 \mathrm{~d}-\mathrm{f}$ & $0.27 \pm 0.034 \mathrm{e}$ & $0.103 \pm 0.013 \mathrm{~b}$ \\
OH-597 & $8.43 \pm 0.61 \mathrm{~b}-\mathrm{f}$ & $0.34 \pm 0.068 \mathrm{c}-\mathrm{e}$ & $0.105 \pm 0.049 \mathrm{~b}$ \\
OH-2324 & $8.75 \pm 0.36 \mathrm{~b}-\mathrm{e}$ & $0.40 \pm 0.046 \mathrm{~b}-\mathrm{e}$ & $0.128 \pm 0.033 \mathrm{~b}$ \\
Okra-1548 & $9.88 \pm 0.37 \mathrm{a}-\mathrm{d}$ & $0.72 \pm 0.029 \mathrm{a}$ & $0.163 \pm 0.016 \mathrm{ab}$ \\
Okra-7080 & $10.18 \pm 0.43 \mathrm{a}-\mathrm{c}$ & $0.55 \pm 0.044 \mathrm{a}-\mathrm{d}$ & $0.143 \pm 0.023 \mathrm{~b}$ \\
Kiran & $10.08 \pm 0.41 \mathrm{ad}$ & $0.58 \pm 0.039 \mathrm{a}-\mathrm{c}$ & $0.130 \pm 0.021 \mathrm{~b}$ \\
Sitara-9101 & $7.40 \pm 0.70 \mathrm{c}-\mathrm{f}$ & $0.42 \pm 0.062 \mathrm{~b}-\mathrm{e}$ & $0.105 \pm 0.028 \mathrm{~b}$ \\
Okra-7100 & $8.50 \pm 0.82 \mathrm{~b}-\mathrm{f}$ & $0.55 \pm 0.045 \mathrm{a}-\mathrm{d}$ & $0.150 \pm 0.021 \mathrm{ab}$ \\
Click-5769 & $5.58 \pm 0.50 \mathrm{f}$ & $0.62 \pm 0.051 \mathrm{ab}$ & $0.138 \pm 0.015 \mathrm{~b}$ \\
JKOH-456 & $7.38 \pm 0.55 \mathrm{c}-\mathrm{f}$ & $0.46 \pm 0.031 \mathrm{~b}-\mathrm{e}$ & $0.143 \pm 0.035 \mathrm{~b}$ \\
Rama Krishna & $11.20 \pm 0.77 \mathrm{ab}$ & $0.53 \pm 0.054 \mathrm{a}-\mathrm{d}$ & $0.150 \pm 0.030 \mathrm{ab}$ \\
Garnier & $8.63 \pm 0.77 \mathrm{~b}-\mathrm{e}$ & $0.59 \pm 0.067 \mathrm{ab}$ & $0.148 \pm 0.014 \mathrm{~b}$ \\
Tokita & $8.63 \pm 0.77 \mathrm{~b}-\mathrm{e}$ & $0.39 \pm 0.039 \mathrm{~b}-\mathrm{e}$ & $0.280 \pm 0.014 \mathrm{a}$ \\
Green Gold & $8.30 \pm 0.91 \mathrm{~b}-\mathrm{f}$ & $0.53 \pm 0.053 \mathrm{a}-\mathrm{d}$ & $0.108 \pm 0.029 \mathrm{~b}$ \\
\hline
\end{tabular}

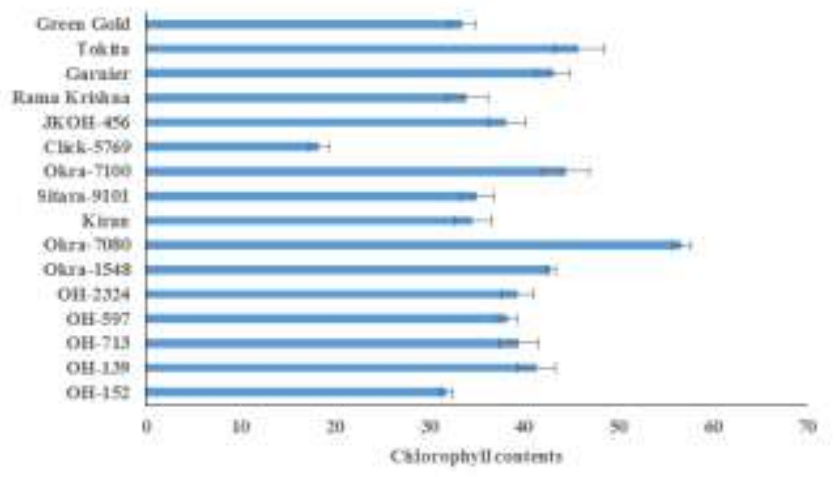

Figure 1. 
Proc. of the Fourth Intl. Conf. Advances in Bio-Informatics, Bio-Technology and Environmental Engineering- ABBE 2016 Copyright (c) Institute of Research Engineers and Doctors, USA .All rights reserved.

ISBN: 978-1-63248-091-0 doi: 10.15224/ 978-1-63248-091-0-38

\section{B. Physiological parameters}

Sub-stomatal $\mathrm{CO}_{2}$, transpiration rate, Stomatal Conductance, water use efficiency, leaf temperature and chlorophyll content were recorded highly significant. Maxim amount of sub-stomatal $\mathrm{CO} 2$ was observed in $\mathrm{OH}-139$ (951.75) followed by OH-2329 (943.25) whereas minimum amount of sub-stomatal $\mathrm{CO} 2$ was calculated in Tokita (422.00). Maximum transpiration rate was recorded in Click-5769 (2.44) followed by the Rama Krishna (1.97) whereas least amount was calculated in $\mathrm{OH}-152(0.79)$.

Out of 16 genotypes the chlorophyll content in Okra-7080 (56.83) was found to be maximum followed by Okra -7100 (44.43). However, least amount of chlorophyll was calculated in click-5769 (18.30).Stomatal conductance water was calculated maximum in Click-5769 (0.108) followed by Okra-7100 (0.63) while minimum in OH-713 (0.038). Photosynthetic rate found highest in $\mathrm{OH}-152$ (4.67) followed by Garniar (3.13) while was minimum in $\mathrm{OH}-1548$ (0.51) followed by OH-2324 (0.30) Water use efficiency was fund maximum to be in $\mathrm{OH}-152$ (7.24) followed by $\mathrm{OH}-713$ (2.99) while, minimum was recorded in $\mathrm{OH}-2324$ (0.31) Leaf temperature was found maximum Green Gold (33.23), followed by Tokita, Garnier (33.15) at park, while minimum leaf temperature was measured in OH-152 (28.78). Out of all selected genotypes the chlorophyll content in Okra-7080 (56.83) was found to be maximum followed by Okra -7100 (44.43). However, least amount of chlorophyll was calculated in click-5769 (18.30).

Table 3 Overall comparison of mean values $(n=3)$ of substomatal $\mathrm{CO}_{2}$, transpiration rate and stomatal conductance of water of okra genotypes

\begin{tabular}{llll}
\hline Genotypes & Sub-stomatal CO & $\begin{array}{l}\text { Transpiration } \\
\text { Rate }\end{array}$ & $\begin{array}{l}\text { Stomatal } \\
\text { Cond. Water }\end{array}$ \\
\hline OH-152 & $915.75 \pm 68.15 \mathrm{a}-\mathrm{c}$ & $0.79 \pm 0.15 \mathrm{c}$ & $0.048 \pm 0.008 \mathrm{~b}$ \\
$\mathrm{OH}-139$ & $951.75 \pm 16.30 \mathrm{a}$ & $1.57 \pm 0.11 \mathrm{a}-\mathrm{c}$ & $0.065 \pm 0.006 \mathrm{ab}$ \\
$\mathrm{OH}-713$ & $924.75 \pm 10.37 \mathrm{ab}$ & $1.02 \pm 0.18 \mathrm{bc}$ & $0.038 \pm 0.005 \mathrm{~b}$ \\
$\mathrm{OH}-597$ & $892.75 \pm 31.33 \mathrm{a}-\mathrm{c}$ & $1.24 \pm 0.21 \mathrm{bc}$ & $0.053 \pm 0.013 \mathrm{ab}$ \\
$\mathrm{OH}-2324$ & $943.25 \pm 4.71 \mathrm{a}$ & $1.56 \pm 0.15 \mathrm{a}-\mathrm{c}$ & $0.060 \pm 0.007 \mathrm{ab}$ \\
Okra-1548 & $935.50 \pm 1.44 \mathrm{ab}$ & $1.69 \pm 0.13 \mathrm{a}-\mathrm{c}$ & $0.060 \pm 0.006 \mathrm{ab}$ \\
Okra-7080 & $880.25 \pm 14.73 \mathrm{a}-\mathrm{c}$ & $1.63 \pm 0.13 \mathrm{a}-\mathrm{c}$ & $0.058 \pm 0.006 \mathrm{ab}$ \\
Kiran & $884.25 \pm 12.58 \mathrm{a}-\mathrm{c}$ & $1.68 \pm 0.18 \mathrm{a}-\mathrm{c}$ & $0.058 \pm 0.009 \mathrm{ab}$ \\
Sitara-9101 & $798.25 \pm 8.52 \mathrm{~b}-\mathrm{e}$ & $1.41 \pm 0.22 \mathrm{a}-\mathrm{c}$ & $0.053 \pm 0.011 \mathrm{ab}$ \\
Okra-7100 & $777.50 \pm 11.43 \mathrm{c}-\mathrm{e}$ & $1.62 \pm 0.13 \mathrm{a}-\mathrm{c}$ & $0.063 \pm 0.006 \mathrm{ab}$ \\
Click-5769 & $833.25 \pm 6.24 \mathrm{a}-\mathrm{d}$ & $2.44 \pm 0.42 \mathrm{a}$ & $0.108 \pm 0.027 \mathrm{a}$ \\
JKOH-456 & $679.75 \pm 18.64 \mathrm{ef}$ & $1.88 \pm 0.23 \mathrm{ab}$ & $0.073 \pm 0.010 \mathrm{ab}$ \\
Rama Krishna & $733.25 \pm 14.53 \mathrm{de}$ & $1.97 \pm 0.07 \mathrm{ab}$ & $0.070 \pm 0.004 \mathrm{ab}$ \\
Garnier & $560.25 \pm 71.23 \mathrm{fg}$ & $1.77 \pm 0.34 \mathrm{a}-\mathrm{c}$ & $0.063 \pm 0.019 \mathrm{ab}$ \\
Tokita & $422.00 \pm 16.23 \mathrm{~g}$ & $1.57 \pm 0.26 \mathrm{a}-\mathrm{c}$ & $0.050 \pm 0.012 \mathrm{ab}$ \\
Green Gold & $577.50 \pm 13.42 \mathrm{f}$ & $1.77 \pm 0.16 \mathrm{a}-\mathrm{c}$ & $0.058 \pm 0.008 \mathrm{ab}$ \\
\hline
\end{tabular}

Table 4 Overall comparison of mean values $(n=3)$ of Photosynthetic rate, water use efficiency and leaf temperature of okra genotypes

\begin{tabular}{llll}
\hline Genotypes & $\begin{array}{l}\text { Photosynthetic } \\
\text { Rate }\end{array}$ & $\begin{array}{l}\text { Water Use } \\
\text { Efficiency }\end{array}$ & Leaf Temperature \\
\hline OH-152 & $4.67 \pm 0.35 \mathrm{a}$ & $7.24 \pm 0.72 \mathrm{a}$ & $28.78 \pm 0.87 \mathrm{~d}$ \\
$\mathrm{OH}-139$ & $1.92 \pm 0.14 \mathrm{~b}-\mathrm{d}$ & $1.27 \pm 0.20 \mathrm{bc}$ & $32.05 \pm 0.37 \mathrm{a}-\mathrm{c}$ \\
$\mathrm{OH}-713$ & $2.81 \pm 0.48 \mathrm{a}-\mathrm{c}$ & $2.99 \pm 0.66 \mathrm{~b}$ & $31.43 \pm 0.82 \mathrm{bc}$ \\
$\mathrm{OH}-597$ & $1.84 \pm 0.38 \mathrm{~b}-\mathrm{d}$ & $1.76 \pm 0.57 \mathrm{bc}$ & $30.48 \pm 0.18 \mathrm{~cd}$ \\
$\mathrm{OH}-2324$ & $0.30 \pm 0.17 \mathrm{~d}$ & $0.13 \pm 0.13 \mathrm{c}$ & $31.83 \pm 0.26 \mathrm{a}-\mathrm{c}$ \\
Okra-1548 & $0.51 \pm 0.05 \mathrm{~d}$ & $0.31 \pm 0.06 \mathrm{c}$ & $32.55 \pm 0.03 \mathrm{ab}$ \\
Okra-7080 & $1.62 \pm 0.67 \mathrm{~b}-\mathrm{d}$ & $0.92 \pm 0.36 \mathrm{bc}$ & $32.88 \pm 0.07 \mathrm{ab}$ \\
Kiran & $1.28 \pm 0.41 \mathrm{~b}-\mathrm{d}$ & $0.71 \pm 0.19 \mathrm{c}$ & $33.13 \pm 0.07 \mathrm{ab}$ \\
Sitara-9101 & $1.74 \pm 0.30 \mathrm{~b}-\mathrm{d}$ & $1.33 \pm 0.31 \mathrm{bc}$ & $31.78 \pm 0.20 \mathrm{a}-\mathrm{c}$
\end{tabular}

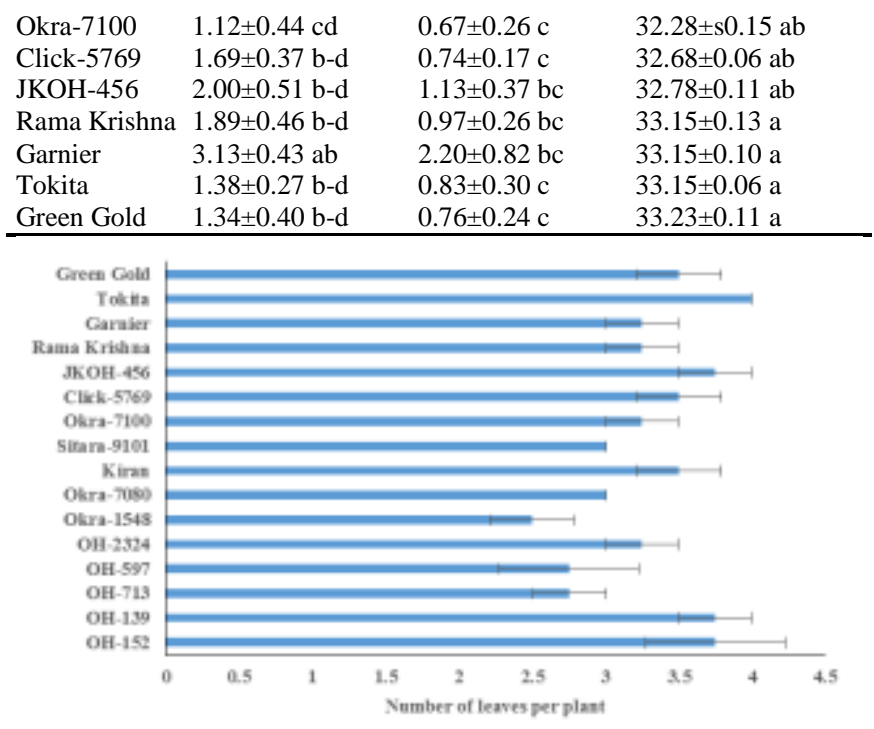

Figure 2.

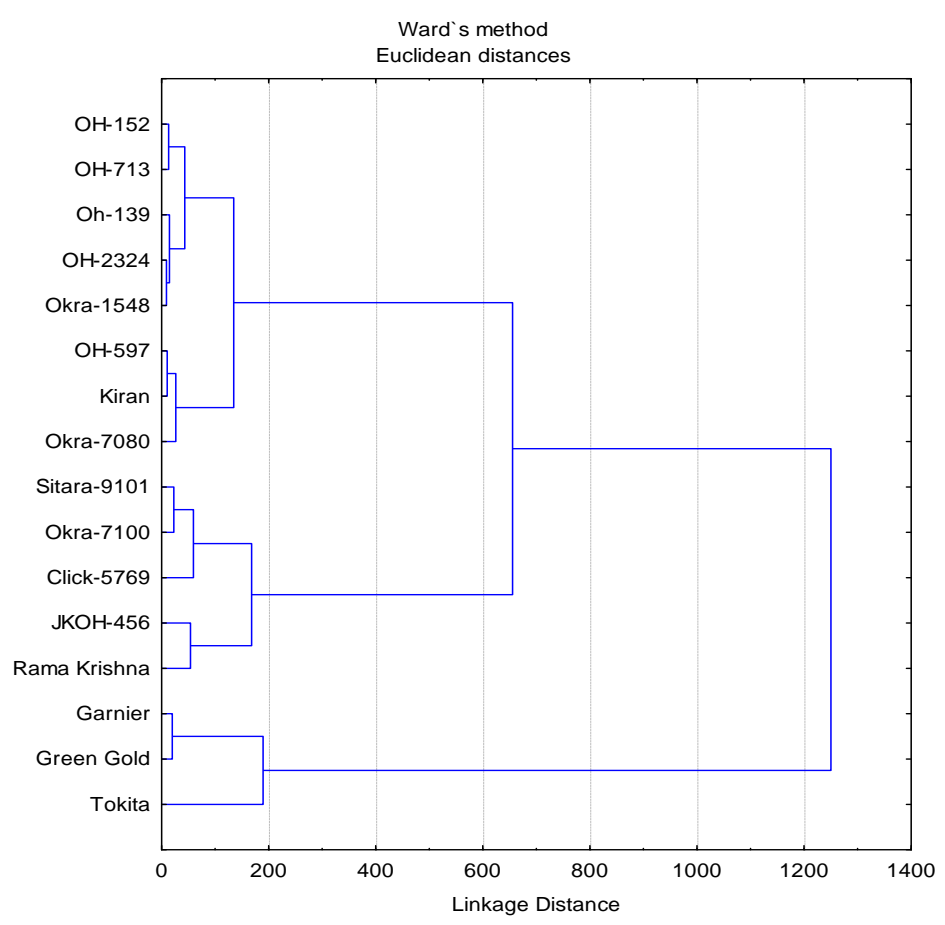

Figure 3.

\section{Discussion}

In present investigation, 16 okra cultivars were subjected to heat stress in order to screen them on the bases of their tolerance against the heat stress. On the basis of various growth attributes at seedling stage the result of this study showed that all parameters were affected significantly by the heat stress. Observed the wilting of seedlings, reduced leaves size, induced senescence and change of colour from green to yellow black, drastic decrease in fresh and dry matter contents reason can be the high transpiration rate disturbance or injuries in the physiological processes 
occurring within cell (Schoffl et al.,1999).Out of all selected genotypes shoot length was observed to be maximum in $\mathrm{JKOH}-456(12.23 \mathrm{~cm})$ followed by the click-5769 and $\mathrm{OH}-$ $152(11.75 \mathrm{~cm})$ which were at par, while minimum length was in okra-1548 $(7.75 \mathrm{~cm})$ Root length were found to be maximum in Rama Krishna $(11.20 \mathrm{~cm})$ followed by kiran $(10.08 \mathrm{~cm})$ and lowest length was of Click-5769 $(5.58 \mathrm{~cm})$ Photosynthesis rate was greater in $\mathrm{OH}-152$ which showed that variety is capable of emitting greater amount of isoprene (Velikova and Loreto, 2005). Sharkey (2005) also viewed that isoprene production protects the PSII from the harm caused by ROS, including $\mathrm{H}_{2} \mathrm{O}_{2}$, produced during heat-induced oxygenase action of rubisco, even though the photosynthetic rate approaches zero. It was proposed that endogenous production of isoprene protects the biological membranes from damaging effects by directly reacting with oxygen singlets $\left(\mathrm{O}_{2}\right)$ by means of isoprene-conjugate double bond (Velikova et al., 2005). Dry matter content was significantly affected by heat stress of reason that heat stress induced modifications in physiological process or may be alter the pattern of development (Weaich et al., 1996). Major effect of high temperature is on shoot length which reduced the first intermodal length resulting in death of plants (Hall, 1992). Heat stress caused significant declines in shoot dry mass, relative growth rate (Ashraf and Hafeez, 2004). Heat stress caused considerable damages including the burning of the leaves and twigs, wilting and burn spots on leaves and stem, leaf senescence (Vollenweider and Gunthardt-Goerg, 2005). Heat stress caused overall reduction in yield ( Giaveno and Ferrero, 2003 ). According to recoded data $\mathrm{OH}-152$ is the most resistant genotypes followed by $\mathrm{OH}-$ 713 , in contrast to it, Garnier, Green gold, are the sensitive ones but Tokita is the most sensitive among all genotypes. In general, high temperature noticeably affected anatomical structures not only at the tissue and cellular levels but also at the sub-cellular level. The collective effects of all these changes under high temperature stress caused poor plant growth and productivity. On the basis of physical parameters (OH-152, KJOH-456, Click-5769) were among the most tolerant group, physiologically most resistant genotypes were (OH-152, Click-5769, OH-139) and biochemically resistant genotype was observed (okra 7080). From the findings of this research trial, it can be extracted that heat stress has a significant effect on the physiology, morphology and biochemical mechanisms and screened the following genotypes is the order against the heat stress $\mathrm{OH}$ 152, OH-139, OH-139, OH-2324, Okra-1548, OH-597, Kiran, Okra-7080, Sitara-910, Okra-7100, Click-5769, JKOJ-456, Rama Krishna, Garnier followed by Tokita.

\section{Conclusion}

Further scope of research is obvious,scientist can work to investigate the signaling machinimas plant adopt at cellular level to encounter heat .

\section{Acknowledgment (Heading 5)}

Special thanks to Australian government for the funding of this project.

\section{References}

[1] J.S. Siemonsma, and C. Kouame. Abelmoschusessculentum. In: G.J.H. Grubben and O.A. Denton (eds.). Plant Resource Trop. Africa. Prota Foundation, Netherlands. 2004. p. 21-29.

[2] K.M. Nandkarni, Indian MeteriaMedica.Nadkarni and Co Bombay. India. 1927

[3] A.A. Abdul-Baki, Tolerance of tomato cultivars and selected germplasm to heat stress. J. Amer. Soc. Hort. Sci. 1991. 116:11131116.

[4] A.E. Hall, Crop Responses to Environment. CRC Press LLC, Boca Raton, Florida, USA. 2001.

[5] P.D. Jones, M. Parker, D.E.S. Mortin, and I.G. Rigor. Surface area temperature and its change over the past 150 years. Rev. Geophys. 1999. 37:173-199.

[6] C.J. Howarth, Genetic improvements of tolerance to high temperature. In: M. Ashraf, P.J.C. Harris (eds.). Abiotic Stresses: Plant Resistance Through Breeding and Molecular Approaches. Howarth Press Inc., New York, USA. 2005.

[7] A. Janska, P. Marsik, S. Zelenkova, and J. Ovesna. Cold stress and acclimation: What is important for metabolic adjustment Plant Biol. 2010, 12: 395-405.

[8] F. Schoff, R, Prand, and A. Reind. Molecular responses to heat stress. In: Shinozaki, K.,Yamaguchi-Shinozaki, K. (Eds.), Molecular Responses to Cold, Drought, Heat and Salt Stress in Higher Plants. R.G. LandesCo.,Austin, Texas, 1999. pp. 81-98.

[9] V. Velikova, A. Edreva, and F. Loreto. Endogenous isoprene protects Phragmitesaustralis leaves against singlet oxygen. Plant Cell Environ. 2005. 28:318-327.

[10] K. Weaich, K.L. Bristonand, and A. Cass. Modeling pre-emergent maize shoot growth. II. High temperature stress conditions. Agric. J. 1996. 88:398-403.

[11] T.D. Sharkey. Effects of moderate heat stress on photosynthesis: importance of thylakoid reactions, rubisco deactivation, reactive oxygen species, and thermo-tolerance provided by isoprene. Plant Cell Environ. 2005. 28:269-277.

[12] M. Ashraf, and M. Hafeez. Thermo tolerance of pearl millet and maize at early growth stages: growth and nutrient relations. Biol. Plant. 2004. 3:89-94.

[13] C. Giaveno, and J. Ferrero. Introduction of tropical maize genotypes to increase silage production in the central area of Santa Fe, Argentina. Crop Breed. Appl. Biotechnol. 2003. 48:81-86.G. Eason, B. Noble, and I. N. Sneddon, "On certain integrals of Lipschitz-Hankel type involving products of Bessel functions," Phil. Trans. Roy. Soc. London, vol. A247, pp. 529-551, April 1955. (references)

About Author (s)

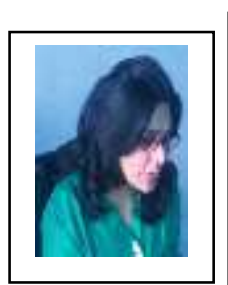

\begin{tabular}{|c|}
\hline Sumeera Asghar \\
A passionate Pakistani researcher. \\
Recently completed M.Phil in plant \\
sciences. Working as visiting faculty at \\
Muhammad nawaz Shareef University of \\
Agriculture Multan. \\
\hline
\end{tabular}

